\title{
EGFR NP_005219.2:p.L747_K754del
}

National Cancer Institute

\section{Source}

National Cancer Institute. EGFR NP 005219.2:p.L747 K754del. NCI Thesaurus. Code C98556.

A deletion of eight amino acids from the epidermal growth factor receptor protein from the leucine at position 747 through the lysine at position 754 . 